\title{
Determination of physical and chemical quality of coffee beans under improved potassium fertilization managements
}

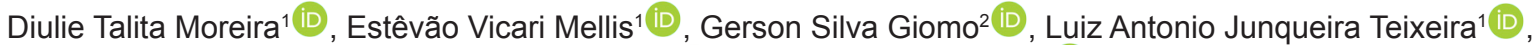 \\ Edilson Cavalli ${ }^{3}$ (D), Lucas Ferreira Ramos ${ }^{4}$ (D)
}

\author{
${ }^{1}$ Instituto Agronômico de Campinas/IAC, Departamento de Solos e Recursos Ambientais, Campinas, São Paulo, Brasil \\ 2Instituto Agronômico de Campinas/IAC, Centro de Café "Alcides Carvalho", Campinas, São Paulo, Brasil \\ ${ }^{3}$ Instituto Federal de Mato Grosso/IFMT, Guarantã no Norte, Mato Grosso, Brasil \\ ${ }^{4}$ Instituto Agronômico de Campinas/PGIAC, Campinas, São Paulo, Brasil \\ Contact authors: diulie.moreira@daterracoffee.com.br; estevao.mellis@sp.gov.br; gsgiomo@gmail.com; luiz.teixeira@sp.gov.br; edilso_c@hotmail.com; lucasframos5026@hotmail.com \\ Received in February 19, 2021 and approved in July 2, 2021
}

\section{ABSTRACT}

Coffee quality is the key attribute for establishing its price and commercialization. As the classification of coffee quality is a complex process, mainly based on a subjective judgment, difficult to define and measure, a complementary approach to the current procedures involving physical and chemical methods would bring more effectiveness to the process of quality determination. The chemical composition of the coffee bean is influenced by several factors, among them the nutritional management of coffee trees and, the use of potassium chloride (KCl), which has intensified losses in bean quality due to excessive chlorine in its composition. The aim of this study was to evaluate the efficiency of sources and forms of $\mathrm{K}$ application in the quality of beans, and assessment of methodologies for determination of physical and chemical qualities of beans. The experiment was conducted with Yellow Catuaí cultivar, from 2017 to 2019, in a randomized experimental block design with five replicates. Six treatments were applied, containing proportions of $\mathrm{KCl} / \mathrm{K}_{2} \mathrm{SO}_{4}$, as follows: $\mathrm{T} 1-100 \% \mathrm{KCl}$; $\mathrm{T} 2-75 \% / 25 \%$; T3-50\%/50\%; $\mathrm{T} 4-25 \% / 75 \%$; $\mathrm{T} 5-100 \%$ of $\mathrm{K}_{2} \mathrm{SO}_{4}$ and $\mathrm{T} 6-100 \%$ of $\mathrm{KCl}+$ two foliar $\mathrm{K} 2 \mathrm{SO}$ applications. The variables addressed in the study were sensory analysis, screen of beans, electrical conductivity (EC), potassium leaching (KL), titratable total acidity (TTA), and coffee bean color. It was verified that $\mathrm{KL}, \mathrm{EC}$, and other chromatic parameters were efficient in detecting alterations on coffee bean caused by the use of KC1. Total (T5) or partial (T4) replacement of $\mathrm{KC1}$ by $\mathrm{K}_{2} \mathrm{SO}_{4}$ applied to soil improved chemical characteristics and color of coffee beans. Supplemental foliar fertilization with $\mathrm{K}_{2} \mathrm{SO}_{4}$ (T6) was efficient to minimize deleterious effects of $\mathrm{KCl}$ on quality of coffee beans, improving beverage quality and grain size, especially in high productive harvests.

Key words: Classification; Coffea arabica L.; foliar fertilization; coffee drink quality.

\section{INTRODUCTION}

Over the last years, the demand for specialty coffee has increased worldwide, generating above-average profits for producers operating in that market. Coffee classification is based on human sensory analysis, cupping, and depends on sensations and personal abilities of coffee tasters, which makes this method susceptible to error. Thus, a small variation in sensory perception might mean a large price difference for the producer. Therefore, the adoption of physical and chemical methods to complement procedures currently in use could help determine the coffee quality in a more objective and precise manner.

Based on that, several scientific studies started to correlate chemical and physical aspects of beans, which are determined in laboratories, such as electrical conductivity (EC), potassium leaching (KL), acidity, $\mathrm{pH}$, humidity and color of beans, with sensory analysis and coffee management (Godinho et al., 2000; Malta; Pereira; Chagas, 2005; Martinez et al., 2014).

Among the factors interfering with the quality of coffee beverage, the nutritional management of crops stands out as the most important ones. Although several nutrients are required by coffee trees, potassium $(\mathrm{K})$ and chlorine $(\mathrm{Cl})$ are among the ones that mostly affect the quality of the bean. K has a positive influence on coffee beans since it is a key element for the control of fungal disease, water stress, and development and size of ripe beans, stimulating enzymatic activities and the synthesis and translocation of carbohydrates, thus improving the quality of coffee beverage (Malavolta; Vitti; Oliveira, 1997; Matiello et al., 2010; Mancuso et al., 2014).

Although the widely known harmful effect of $\mathrm{Cl}$ on coffee the quality as a decrease in polyphenoloxidase activity, increase in total titratable acidity, decrease in color index and total sugar content as observed by Silva et al. (1999), fertilization with potassium chloride $(\mathrm{KCl})$ prevails in Brazilian agriculture due to its greater availability and lower cost (Ernani; Almeida; Santos, 2007). Studies on the effect of $\mathrm{K}$ doses provided by $\mathrm{KCl}, \mathrm{K}_{2} \mathrm{SO}_{4}$ and $\mathrm{KNO}_{3}$ sources in Brazil (Silva et al., 1999; Silva; Nogueira; Guimarães, 2002) demonstrated that fertilization using $\mathrm{C} 1$-free sources provided a better quality in Coffea arabica L., especially $\mathrm{K}_{2} \mathrm{SO}_{4}$. One alternative would be the partial replacement of $\mathrm{KCl}_{\text {by }} \mathrm{K}_{2} \mathrm{SO}_{4}$ or the complementation of $\mathrm{K}$ fertilization with foliar applications of $\mathrm{K}_{2} \mathrm{SO}_{4}$ to coffee trees. However, due to the higher cost of $\mathrm{K}_{2} \mathrm{SO}_{4}$, its use still needs to be backed up by better responses of production and quality of the coffee beverage. 
Studies with different crops demonstrated that foliar K application, especially $\mathrm{K}_{2} \mathrm{SO}_{4}$, can increase productivity and quality of products (Jifon; Lester, 2009; Dkhil; Denden; Aboud 2011; Salim; Abd El-Gawad; Abou El-Yazied, 2014; Abid; Schneider; Scheffran, 2016; Shen et al., 2016; Dalal; Beniwal, 2017; Solhjoo; Gharaghani; Fallahi, 2017). However, studies on this technology for coffee cultivation are still scarce.

This study aimed to evaluate the effectiveness of methodologies for determination of the effects of managements of $\mathrm{K}$ fertilization on the quality of coffee beans.

\section{MATERIAL AND METHODS}

The experiment was set up in November 2016, in Altinópolis, state of São Paulo (SP), Brazil, at an altitude of $903 \mathrm{~m}\left(20^{\circ} 58^{\prime} 12^{\prime \prime} \mathrm{N}\right.$; $47^{\circ} 23^{\prime} 49^{\prime}$ 'W), in clayey Oxisol. The monthly temperature and rainfall averages are shown in Figure 1. For the experiment, a crop of the species Coffea arabica L. from the cultivar Yellow Catuaí implemented in 2010 was used in a spacing of $3.5 \times 0.6 \mathrm{~m}$. Additional irrigations were applied during the flowering and sticking phase by means of a central pivot accounting for approximately 60-80 $\mathrm{mm}$ per month until November. Coffee beans harvested in 2017/2018 and 2018/2019 were used in the analysis and evaluations.

Prior to setting up the experiment, soil samples were collected at depths of 0-0.2 $\mathrm{m}$ and 0.2-0.4 m, and soil fertility characterized according to the methodology as described by Raij et al. (2001). As shown in Table 1, the soil presented adequate fertility conditions for coffee, except for the content of $\mathrm{B}$, which was low.
The experimental design adopted was randomized blocks, with six treatments and five replicates. The plots consisted of three tree lines containing ten plants per line and the useful area of each plot was made up by the eight plants in the center of the parcel. Six K treatments ( $200 \mathrm{~kg} \mathrm{ha}{ }^{1}$ of $\mathrm{K}_{2} \mathrm{O}$ ) were applied, being five of them composed of different proportions of $\mathrm{KCl}$ and $\mathrm{K}_{2} \mathrm{SO}_{4}$ sources. The fertilizers were spread evenly on the soil surface in the canopy projection area. The sixth treatment was composed of $\mathrm{KCl}$ applied to the soil, plus two supplemental foliar applications of $\mathrm{K}_{2} \mathrm{SO}_{4}$ (Table 2). In addition to $\mathrm{K}$, phosphorus (P), nitrogen $(\mathrm{N})$, calcium $(\mathrm{Ca})$ and boron $(\mathrm{B})$ were applied annually following doses: $20 \mathrm{~kg} \mathrm{ha}^{-1}$ of $\mathrm{P}_{2} \mathrm{O}_{5}, 250 \mathrm{~kg} \mathrm{ha}^{-1}$ of $\mathrm{N}, 148 \mathrm{~kg} \mathrm{ha}^{-1}$ of $\mathrm{Ca}$ and $2.4 \mathrm{~kg} \mathrm{ha}^{-1}$ of $\mathrm{B}$ through mono-ammonium phosphate and ammonium nitrate + boric acid, according to Raij et al. (1997). The annual doses of fertilizers were divided into four applications during the months of November through March.

Supplemental foliar application of $\mathrm{K}_{2} \mathrm{SO}_{4}$ was conducted every year in two stages, being the first application done at the end of the flowering period, and the second at the beginning of the bean filling phase. The applications were performed before 8:00 a.m. using a manual knapsack sprayer with a spray volume equivalent to $400 \mathrm{~L} \mathrm{ha}^{-1}$. The dose of $\mathrm{K}_{2} \mathrm{SO}_{4}$ in each application was equivalent to $3 \% \mathrm{~m} . \mathrm{m}^{-1}$ totaling $12.5 \mathrm{~kg} \mathrm{ha}^{-1}$ of $\mathrm{K}_{2} \mathrm{O}$.

For the evaluations, the beans produced by the eight plants in the center of each parcel were manually harvested. After harvesting, the fresh beans were washed, pulped, and dried in air sieves until reaching about $12 \%$ moisture content and then processed, and parchment removed. The yield of the experimental area was 80 bags per hectare in the 2017/2018 harvest and 4 bags per hectare in the 2018/2019 harvest.

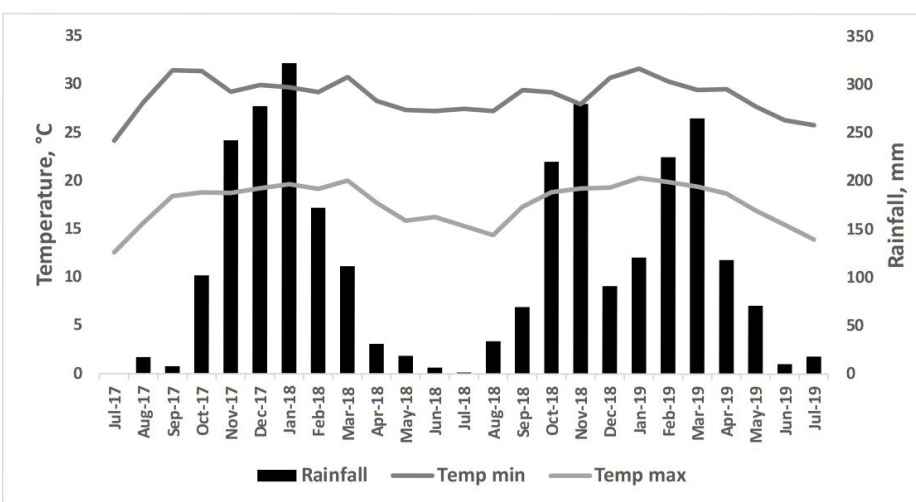

Figure 1: Average monthly rainfall, maximum and minimum temperature in Altinópolis, Brazil. Source of data: (Centro Integrado de Informações Agrometeorológicas - CIAGRO, 2020).

Table 1: Soil fertility parameters prior to the experiment set up.

\begin{tabular}{|c|c|c|c|c|c|c|c|c|c|c|c|c|c|c|}
\hline Depth & $\mathrm{OM}^{1}$ & $\mathrm{pH}^{2}$ & $\mathrm{P}^{3}$ & $\mathrm{~K}^{3}$ & $\mathrm{Ca}^{3}$ & $\mathrm{Mg}^{3}$ & $\mathrm{H}+\mathrm{Al}$ & $\mathrm{S}^{4}$ & $\mathrm{~B}^{5}$ & $\mathrm{Cl}^{6}$ & $\mathrm{Cu}^{6}$ & $\mathrm{Fe}^{6}$ & $\mathrm{Mn}^{6}$ & $\mathrm{Zn}^{6}$ \\
\hline $\mathrm{m}$ & $\mathrm{g} \mathrm{dm}^{-3}$ & & $\mathrm{mg} \mathrm{dm}{ }^{-3}$ & \multicolumn{5}{|c|}{----- $\mathrm{mmol}_{\mathrm{c}} \mathrm{dm}^{-3}$----- } & \multicolumn{6}{|c|}{ - } \\
\hline $0-0.2$ & 30.2 & 5.1 & 160.2 & 3.4 & 26.2 & 10.0 & 35.4 & 10.2 & 0.3 & 36.3 & 12.5 & 41.2 & 11.0 & 4.9 \\
\hline $0.2-0.4$ & 27.6 & 5.4 & 85.2 & 2.6 & 25.6 & 11.2 & 25.4 & 8.6 & 0.2 & 32.4 & 7.9 & 33.0 & 6.2 & 2.2 \\
\hline
\end{tabular}

${ }^{1}$ Organic matter; ${ }^{2} \mathrm{CaCl}_{2}$ solution $0.01 \mathrm{~mol} \mathrm{L-1}$. Extractors: ${ }^{3}$ ion-exchange resin; ${ }^{4} \mathrm{Ca}\left(\mathrm{H}_{2} \mathrm{PO}_{4}\right)_{2} 0.01 \mathrm{~mol} \mathrm{~L}^{-1} ;{ }^{5}$ hot water and ${ }^{5} \mathrm{DTPA}$. 
Table 2: Characterization of the treatments applied.

\begin{tabular}{ccc}
\hline \multirow{2}{*}{ Treatments } & \multicolumn{2}{c}{ K sources (\%) } \\
\cline { 2 - 3 } & $\mathrm{KCl}$ & $\mathrm{K}_{2} \mathrm{SO}_{4}$ \\
\hline 1 & 100 & 0 \\
2 & 75 & 25 \\
3 & 50 & 50 \\
4 & 25 & 75 \\
5 & 0 & 100 \\
6 & 100 & 2 foliar applications \\
\hline
\end{tabular}

\subsection{Evaluations}

\subsubsection{Sensory analysis and physical classification by size}

The beverage quality was determined through sensory analysis performed in the Coopercitrus cupping laboratory at Altinópolis (SP). For that purpose, about $0,5 \mathrm{~kg}$ of processed samples collected from each plot were used. For the 2017/2018 harvest, only ripe beans were separated for processing and quality determination. However, for the 2018/2019 harvest, the separation could not be made due to low productivity. The evaluation of sensory attributes was performed through tasting by qualified and experienced tasters ( $Q$-grader $)$, according to the methodology proposed by the Specialty Coffee Association (Specialty Coffee Association - SCA, 2012), which takes into account the following attributes: clean cup, sweetness, body, flavor, aftertaste, balance or uniformity, and overall score.

For the classification by sieve, $0,3 \mathrm{~kg}$ of processed coffee beans from each sample were weighed and placed on sieves arranged in decreasing order. Then, the beans retained in each sieve were weighed, and the set of beans retained in sieves $18 / 17,16 / 15$, including those smaller than 15 , were presented. The results were expressed as percentages.

\subsubsection{Bean chloride contents}

A sample weighing about $0,1 \mathrm{~kg}$ of beans was dried in oven at $60{ }^{\circ} \mathrm{C}$, and then ground for determination of $\mathrm{Cl}$ content, according to the methodology as proposed by Camargo et al. (2009).

\subsubsection{Electrical conductivity (EC) and potassium leaching (KL)}

The determination of EC and KL in coffee beans was based on an adaptation of the methodology proposed by Prete (1992) apud Marques et al. (2008). The samples were divided into defective and non-defective beans. Four samples containing 50 beans collected from each plot were weighed and immersed in $0,075 \mathrm{~L}$ of deionized water (in $0,18 \mathrm{~L}$ plastic cups) and then placed in a ventilated oven at $25^{\circ} \mathrm{C}$.
After soaking for 5 hours, the solutions containing no coffee beans were poured into another container for EC measuring by a conductivity meter. Results were expressed in $\mu \mathrm{S} \mathrm{cm}^{-1} \mathrm{~g}^{-1}$ of sample. Right after the EC reading, the $\mathrm{KL}$ in the solution was measured by a flame photometer and results expressed in $\mathrm{mg} \mathrm{L}^{-1}$.

\subsubsection{Total titratable acidity (TTA) and pH}

Determination of titratable TTA was performed by titration with $0.1 \mathrm{~N} \mathrm{NaOH}$, according to an adaptation of the methodology mentioned by (Association of Official Agricultural Chemists - AOAC, 2005). In this methodology, $0.01 \mathrm{~kg}$ of ground raw coffee was weighed, and $0,075 \mathrm{~L}$ of $80 \%$ alcohol was added and then stirred for 16 hours. After that, filtration was done through a filter paper, and $0,025 \mathrm{~L}$ was removed from the filtered solution and placed in an erlenmeyer flask containing approximately $0,075 \mathrm{~L}$ of distilled water. The TA was determined by titration with $0.1 \mathrm{NaOH}$ to an end point of $\mathrm{pH} 8.2$ at room temperature measured by $\mathrm{pH}$ meter.

\subsubsection{Color}

In the specific case of green and processed coffee beans, the international standard for measurement follows the CIE system (Commision Internationale de Eclairage) $\mathrm{L} * \mathrm{a} * \mathrm{~b} *$, which is adopted by SCA, the Specialty Coffee Association (SCA, 2012). This system uses spatial coordinates in the Cartesian plane, where $\mathrm{L}^{*}$ coordinate indicates luminosity and is related to the degree of darkening of the material, representing how much lighter or darker the sample is, with values ranging from 0 (totally black) to 100 (completely white). The chromaticity coordinate $\mathrm{a}^{*}$ can assume values from -80 (green) to +100 (red) and the chromaticity coordinate b* can vary from -50 (blue) to +70 (yellow) (Minolta, 1998). By reading the reflectance, the parameters for color analysis of the different treatments were determined using a colorimeter model CR400 (Minolta, Konica Minolta Sensing, Inc. Japan).

\subsubsection{Statistical Analysis}

Data were submitted to descriptive analysis and normality tests. Afterward, the analysis of variance (ANOVA) was applied. The means of the different evaluations according to the K treatments were compared with Tukey's HSD test $(\alpha=0.05)$. Pearson's correlation was performed to measure the degree of association between variables.

\section{RESULTS}

\subsection{Content of $\mathrm{Cl}$ in beans and coffee cupping}

The contents of $\mathrm{Cl}$ in processed raw beans and the description of the sensory classification as a result of the $\mathrm{K}$ fertilization management are shown in Table 3. For the $2017 / 2018$ harvest, the content of $\mathrm{Cl}$ in treatments where $\mathrm{K}$ 
fertilization was $100 \%$ supplied by $\mathrm{KCl}$ in the soil ( $\mathrm{T} 1$ and T6), the content of $\mathrm{Cl}$ in processed raw beans was $405.5 \mathrm{mg}$ $\mathrm{kg}^{-1}$ on average, while in treatments with $\mathrm{K}_{2} \mathrm{SO}_{4}$ (T5) the $\mathrm{C} 1$ content was $307 \mathrm{mg} \mathrm{kg}^{-1}$. For the 2018/2019 harvest, the $\mathrm{Cl}$ bean contents in $\mathrm{T} 1$ and $\mathrm{T} 6$ treatments were $679.5 \mathrm{mg} \mathrm{kg}^{-1}$ of $\mathrm{Cl}$, decreasing to $539 \mathrm{mg} \mathrm{kg}^{-1}$ in $\mathrm{T} 5$. The $\mathrm{K}_{2} \mathrm{SO}_{4}$ foliar applications did not cause a decrease in bean $\mathrm{C} 1$ content.

Regarding the coffee cupping of the 2017/2018 harvest, the scores varied from 78 for $\mathrm{T} 1(100 \% \mathrm{KCl})$ to 80 for T6 $\left(100 \% \mathrm{KCl}+\right.$ foliar $\left.\mathrm{K}_{2} \mathrm{SO}_{4}\right)$. Despite the low variation and the fact that there were no statistical differences between treatments, the application of $\mathrm{K}_{2} \mathrm{SO}_{4}$ via leaf enabled the coffee to be classified as special according to the scale used by SCA
(2012). The other treatments showed scores between 78 and 79 points, with variation ranging from regular to good quality coffees. The average score for the 2018/2019 harvest was 79, regardless of treatments, being classified as normal to a good quality, according to the SCA (2012) protocol.

\subsection{Classification by sieves}

The classification of physical characteristics through sieves as a result of treatments is described in Table 4. Statistical differences among sieves in relation to treatments were observed only in the $2018 / 2019$ harvest. The T6 treatment $\left(100 \% \mathrm{KCl}+\right.$ two foliar applications of $\left.\mathrm{K}_{2} \mathrm{SO}_{4}\right)$ stood out as the highest percentage of beans retained in sieves greater than

Table 3: $\mathrm{C} 1$ content, quality scores and classification according to the management of $\mathrm{K}$ fertilization in coffee beans processed in the $2017 / 2019$ biennium.

\begin{tabular}{|c|c|c|c|c|c|c|}
\hline Treatments $^{1}$ & $\mathrm{Cl}$ & Score & Classification & $\mathrm{Cl}$ & Score & Classification \\
\hline & $\mathrm{mg} \mathrm{kg}^{-1}$ & - & - & $\mathrm{mg} \mathrm{kg}^{-1}$ & - & - \\
\hline & \multicolumn{3}{|c|}{--------------2017/2018--------------- } & \multicolumn{3}{|c|}{-------------2018/2019------------- } \\
\hline $\mathrm{T} 1$ & 418 a & 78 & Good normal & $661 \mathrm{ab}$ & 79 & Good normal \\
\hline $\mathrm{T} 2$ & $417 \mathrm{a}$ & 78 & Good normal & $637 \mathrm{ab}$ & 79 & Good normal \\
\hline $\mathrm{T} 3$ & $362 \mathrm{ab}$ & 79 & Good normal & $625 \mathrm{ab}$ & 79 & Good normal \\
\hline $\mathrm{T} 4$ & $311 b$ & 79 & Good normal & $566 \mathrm{ab}$ & 79 & Good normal \\
\hline $\mathrm{T} 5$ & $307 \mathrm{~b}$ & 79 & Good normal & $539 \mathrm{~b}$ & 79 & Good normal \\
\hline T6 & $393 \mathrm{ab}$ & 80 & Special & $698 \mathrm{a}$ & 79 & Good normal \\
\hline Mean & 371 & 78.9 & Good normal & 621 & 79.0 & Good normal \\
\hline F value & 4.044 & 1.335 & - & 3.534 & 0.944 & - \\
\hline $\mathrm{CV}$ & 13.99 & 1.4 & - & 11.3 & 0.9 & - \\
\hline
\end{tabular}

1.T1-100\% KCl; T2-75\%/25\%; T3-50\%/50\%; T4-25\%/75\%; T5-100\% of $\mathrm{K}_{2} \mathrm{SO}_{4}$ and T6-100\% of KCl + two foliar $\mathrm{K}_{2} \mathrm{SO}_{4}$ applications. CV: Coefficient of variation in \%; mean values in the same column followed by different letters indicate a significant effect of Turkey test $(p>0.05)$.

Table 4: Effects of K source management on the classification of coffee bean size in sieves (\%) in the biennium 2017/2019.

\begin{tabular}{|c|c|c|c|c|}
\hline \multirow{3}{*}{ Treatments $^{1}$} & \multicolumn{4}{|c|}{ Sieves } \\
\hline & \multicolumn{2}{|c|}{$\geq 15$} & \multicolumn{2}{|c|}{$<15$} \\
\hline & $2017 / 2018$ & $2018 / 2019$ & $2017 / 2018$ & $2018 / 2019$ \\
\hline & \multicolumn{4}{|c|}{ 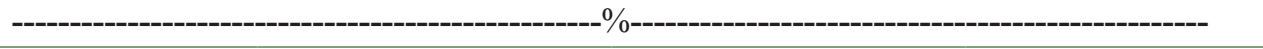 } \\
\hline $\mathrm{T} 1$ & 82 & $85 b$ & 18 & $15 \mathrm{a}$ \\
\hline $\mathrm{T} 2$ & 79 & $84 b$ & 21 & $16 \mathrm{a}$ \\
\hline $\mathrm{T} 3$ & 81 & $87 \mathrm{ab}$ & 19 & $13 \mathrm{ab}$ \\
\hline $\mathrm{T} 4$ & 82 & $91 \mathrm{ab}$ & 18 & $9 a b$ \\
\hline $\mathrm{T} 5$ & 82 & $91 \mathrm{ab}$ & 18 & $9 \mathrm{ab}$ \\
\hline T6 & 82 & $93 a$ & 18 & $7 b$ \\
\hline Average & 81.4 & 88.5 & 18.8 & 11.1 \\
\hline$F$ value & 1.12 & 4.11 & 1.263 & 4.07 \\
\hline $\mathrm{CV} \%$ & 3.19 & 4.76 & 11.7 & 37.4 \\
\hline
\end{tabular}

1.T1-100\% KCl; T2-75\%/25\%; T3-50\%/50\%; T4-25\%/75\%; T5-100\% of $\mathrm{K}_{2} \mathrm{SO}_{4}$ and T6- $100 \%$ of $\mathrm{KCl}+$ two foliar $\mathrm{K}_{2} \mathrm{SO}_{4}$ applications. CV: Coefficient of variation in \%; mean values in the same column followed by different letters indicate a significant effect of Turkey test ( $p>0.05)$. 
15 compared to treatments $\mathrm{T} 1$ and $\mathrm{T} 2$. The other treatments, T3, T4 and T5, presented intermediate results, showing no statistical differences in relation to T6, T2 and T1.

\subsection{Total titratable acidity (TTA), $\mathrm{pH}$, electrical conductivity (EC) and potassium leaching (KL)}

The effect of treatments on TTA, EC, $\mathrm{pH}$ and LK of processed raw coffee beans are shown in Table 5.

For $\mathrm{pH}$, no statistically significant differences between treatments were detected, with values ranging from 4.9 to 5.2 (Table 5). Total titratable acidity (TTA) was not affected by the different forms of $\mathrm{K}$ fertilization either.

Regarding the EC, significant statistical differences were identified in both harvests studied, regardless of the treatments applied, methods of determination, defective or non-defective beans. It was found that non-defective bean samples showed lower EC values than defective bean samples, varying approximately $18 \mu \mathrm{S} \mathrm{cm} \mathrm{cm}^{-1} \mathrm{~g}^{-1}$ between averages of first harvest beans (2017/2018), and $72 \mu \mathrm{S} \mathrm{cm}^{-1} \mathrm{~g}^{-1}$ between averages of second harvest beans (2018/2019).

Concerning the response to $\mathrm{K}$ fertilization, no statistical differences for EC were observed in both defective and no-defective samples of the 2017/2018 harvest. For the 2018/2019 harvest, significant effects were observed only in non-defective samples. The results obtained in this study indicate that both the total replacement of $\mathrm{KCl}$ by $\mathrm{K}_{2} \mathrm{SO}_{4}$ in the soil and the application of supplemental foliar $\mathrm{K}_{2} \mathrm{SO}_{4}$ decreased the effects of $\mathrm{KC} 1$ on EC in non-defective beans (Table 5). T1 treatment presented EC $86 \mu \mathrm{S} \mathrm{cm}^{-1} \mathrm{~g}^{-1}$, while T5 and T6 showed EC 61 and $64 \mu \mathrm{S} \mathrm{cm}^{-1} \mathrm{~g}^{-1}$, respectively.
For the 2017/2018 harvest, T1 and T2 treatments showed the highest KL, 41.83 and $42.16 \mathrm{mg} \mathrm{L}^{-1}$, respectively; T3, T4, T5 and T6 presented lower KL, $35.7 \mathrm{mg} \mathrm{L}^{-1}$, on average. For the 2018/2019 harvest, T1 treatment showed the highest KL, differing statistically from $\mathrm{T} 4$ and $\mathrm{T} 5$, which presented $\mathrm{KL} 38.4 \mathrm{mg} \mathrm{L}^{-1}$, on average. In the same harvest, treatments $\mathrm{T} 2, \mathrm{~T} 3$ and $\mathrm{T} 6$ presented intermediate $\mathrm{KL}$ results.

\subsection{Color analysis}

Results of color analysis of the 2017/2019 harvest are presented in Table 6. No significant statistical differences were observed for the chromatic coordinate " $a$ ". In relation to parameter "L" estimates for 2017/2018 harvest, there was a significant statistical difference among the values observed. The highest values were observed in treatments receiving the maximum percentages of $\mathrm{KCl}$ fertilization in the soil, $\mathrm{T} 1$ and $\mathrm{T} 2$, without $\mathrm{K}$ foliar application.

Average readings of parameter "b" also presented substantial differences. For processed beans receiving $\mathrm{K}$ fertilization with higher percentages of $\mathrm{K}_{2} \mathrm{SO}_{4}$ (T4 and T5) the "b" value was 17.9 , on average, while for treatment composed of $100 \% \mathrm{KC} 1$ the "b" value was 19.1 .

Results of color analysis of coordinate "L", "a" and "b" for the 2018/2019 harvest presented no significant differences.

\subsection{Relationships between variables}

The 2018 harvest presented the highest correlations between chemical or physical attributes of beans and quality scores (Table 7). Negative correlations between quality scores and KL (-0.9), ECD (-0.8) and color parameter "b" (-0.9) were observed. For beans harvested in 2019, no significant

Table 5: Effect of $\mathrm{K}$ source management on electrical conductivity (EC), potassium leaching (KL), $\mathrm{pH}$, and total titratable acidity (TTA) of coffee beans for 2017/2019 biennium.

\begin{tabular}{|c|c|c|c|c|c|c|c|c|c|c|}
\hline \multirow[t]{4}{*}{ Treatments $^{1}$} & \multicolumn{4}{|c|}{$\mathrm{EC}$} & \multicolumn{2}{|c|}{ KL } & \multicolumn{2}{|c|}{$\mathrm{pH}$} & \multicolumn{2}{|c|}{ TTA } \\
\hline & \multicolumn{4}{|c|}{----- $\mu \mathrm{S} \mathrm{cm}^{-1} \mathrm{~g}^{-1}$} & \multicolumn{2}{|c|}{------ $\mathrm{mg} \mathrm{L}^{-1}-----$} & \multicolumn{2}{|c|}{-} & \multicolumn{2}{|c|}{$\mathrm{mL} \mathrm{NaOH} 0,1 \mathrm{~kg}^{-1}$} \\
\hline & \multicolumn{2}{|c|}{ Non-defective } & \multicolumn{2}{|c|}{ Defective } & \multirow[b]{2}{*}{$2017 / 18$} & \multirow[b]{2}{*}{ 2018/19 } & \multirow[b]{2}{*}{$2017 / 18$} & \multirow[b]{2}{*}{$2018 / 19$} & \multirow[b]{2}{*}{$2017 / 18$} & \multirow[b]{2}{*}{$2018 / 19$} \\
\hline & $2017 / 18$ & 2018/19 & $2017 / 18$ & 2018/19 & & & & & & \\
\hline $\mathrm{T} 1$ & 102 & $86 \mathrm{a}$ & 128 & 136 & $41.8 \mathrm{a}$ & $47.5 \mathrm{a}$ & 4.9 & 5.2 & 187 & 207 \\
\hline $\mathrm{T} 2$ & 94 & $75 \mathrm{ab}$ & 110 & 142 & $42.1 \mathrm{a}$ & $40.5 \mathrm{ab}$ & 4.9 & 5.2 & 186 & 196 \\
\hline $\mathrm{T} 3$ & 90 & $71 \mathrm{ab}$ & 110 & 152 & $35.6 \mathrm{~b}$ & $39.8 \mathrm{ab}$ & 4.9 & 5.1 & 186 & 200 \\
\hline $\mathrm{T} 4$ & 95 & $69 \mathrm{ab}$ & 120 & 154 & $35.0 \mathrm{~b}$ & $39.1 \mathrm{~b}$ & 4.9 & 5.2 & 184 & 178 \\
\hline $\mathrm{T} 5$ & 85 & $61 \mathrm{~b}$ & 90 & 136 & $37.0 \mathrm{~b}$ & $37.8 \mathrm{~b}$ & 4.9 & 5.1 & 178 & 176 \\
\hline T6 & 88 & $64 \mathrm{~b}$ & 90 & 139 & $35.5 \mathrm{~b}$ & $39.7 \mathrm{ab}$ & 4.9 & 5.2 & 196 & 235 \\
\hline Means & $92 \mathrm{~b}$ & $71 \mathrm{~b}$ & $110 \mathrm{a}$ & $143 \mathrm{a}$ & 35.8 & 40.7 & 4.9 & 5.1 & 186 & 198 \\
\hline $\mathrm{F}$ value & 0.844 & 5.171 & 1.953 & 2.090 & 5.359 & 3.565 & 1.732 & 1.294 & 1.391 & 1.460 \\
\hline $\mathrm{CV}$ & 15.8 & 12.1 & 22.5 & 8.6 & 5.5 & 10.0 & 0.81 & 2.0 & 5.96 & 20.0 \\
\hline
\end{tabular}

${ }^{1}$.T1-100\% KCl; T2-75\%/25\%; T3-50\%/50\%; T4-25\%/75\%; T5-100\% of $\mathrm{K}_{2} \mathrm{SO}_{4}$ and T6- $100 \%$ of $\mathrm{KCl}+$ two foliar $\mathrm{K}_{2} \mathrm{SO}_{4}$ applications. CV: Coefficient of variation in \%; mean values in the same column followed by different letters indicate a significant effect of Turkey test $(p>0.05)$. 
correlations between quality and physical or chemical attributes were identified. The $\mathrm{Cl}$ content in beans showed a significant correlation with the color parameter $\mathrm{L}^{*}$ in both harvests and with TTA in 2019 (Table 8).

\section{DISCUSSION}

The biennial cycle of coffee is a fairly known effect that characterizes the coffee production in Brazil. Based on that, Silva et al. (2001) suggests the development of long-term studies on fertilization so that the results can be analyzed under a statistical approach accounting for the low and high yields of coffee trees. The results obtained in this study strongly corroborate this need.
In general, $\mathrm{K}$ fertilization had a more remarkable influence on coffee bean quality in 2017/2018. This has probably occurred because only mature beans were separated for analysis, which did not occur in the 2018/2019 harvest as there were not enough beans to compose the samples.

The $\mathrm{C} 1$ content in beans decreased in the same proportion as the amount of $\mathrm{K}_{2} \mathrm{SO}_{4}$ applied to replace $\mathrm{KC}$. In the treatment composed of $100 \% \mathrm{~K}_{2} \mathrm{SO}_{4}$ applied to the soil, the $\mathrm{C} 1$ content in beans showed a reduction of about $22 \%$ as compared to treatments fertilized with 100\% KC1 (T1 and T6) in both harvests. Studies on the effects of sources $\left(\mathrm{K}_{2} \mathrm{SO}_{4} \cdot 2 \mathrm{MgSO}_{4}, \mathrm{~K}_{2} \mathrm{SO}_{4}\right.$ and $\left.\mathrm{KCl}\right)$ and $\mathrm{K}$ doses on the production and quality of coffee beans in two important coffee-producer regions in Brazil, Cerrado and South of Minas (Silva et al., 1999) showed an increase of $24 \%$

Table 6: Effects of K source management on coffee bean color, L* parameter, $a^{*}$ and b*, 2017/2019 harvest.

\begin{tabular}{|c|c|c|c|c|c|c|}
\hline \multirow[t]{3}{*}{ Treatment $^{1}$} & \multicolumn{6}{|c|}{ Mean values of reading } \\
\hline & \multicolumn{2}{|c|}{$\mathrm{L}^{*}$} & \multicolumn{2}{|c|}{$a^{*}$} & \multicolumn{2}{|c|}{$\mathrm{b}^{*}$} \\
\hline & $2017 / 18$ & $2018 / 19$ & $2017 / 18$ & $2018 / 19$ & $2017 / 18$ & $2018 / 19$ \\
\hline $\mathrm{T} 1$ & $54.0 \mathrm{a}$ & 49.7 & 1.9 & 1.3 & $19.1 \mathrm{a}$ & 20.2 \\
\hline $\mathrm{T} 2$ & 53. a & 50.3 & 1.5 & 13 & $18.5 \mathrm{ab}$ & 20.9 \\
\hline $\mathrm{T} 3$ & $51.5 \mathrm{~b}$ & 50.1 & 1.7 & 1.1 & $18.6 \mathrm{ab}$ & 19.9 \\
\hline $\mathrm{T} 4$ & $51.2 \mathrm{~b}$ & 49.2 & 1.5 & 1.2 & $17.9 \mathrm{~b}$ & 20.5 \\
\hline T5 & $51.5 \mathrm{~b}$ & 47.9 & 1.4 & 1.0 & $17.9 \mathrm{~b}$ & 20.6 \\
\hline T6 & $51.6 \mathrm{~b}$ & 50.0 & 1.7 & 1.2 & $18.3 \mathrm{ab}$ & 19.8 \\
\hline Means & 52.3 & 49.6 & 1.6 & 1.2 & 18.4 & 20.5 \\
\hline F value & 7.601 & 1.461 & 2.422 & 1.686 & 2.736 & 0.335 \\
\hline $\mathrm{CV}$ & 2.02 & 4.87 & 17.65 & 48.13 & 3.25 & 9.13 \\
\hline
\end{tabular}

1.T1-100\% KCl; T2-75\%/25\%; T3-50\%/50\%; T4-25\%/75\%; T5- $100 \%$ of $\mathrm{K}_{2} \mathrm{SO}_{4}$ and T6- $100 \%$ of $\mathrm{KCl}+$ two foliar $\mathrm{K}_{2} \mathrm{SO}_{4}$ applications. CV: Coefficient of variation in \%; mean values in the same column followed by different letters indicate a significant effect of Turkey test $(p>0.05)$.

Table 7: Pearson correlation between quality scores and chemical and physical attributes in beans of processed coffee under different $\mathrm{K}$ fertilization managements.

\begin{tabular}{ccccccccccccc}
\hline Year & $\mathrm{Cl}$ & $\mathrm{KL}$ & $\mathrm{pH}$ & $\mathrm{TTA}$ & Moisture & ECND & $\mathrm{ECD}$ & $\mathrm{S}>15$ & $\mathrm{~S}<15$ & $\mathrm{~L}^{*}$ & $\mathrm{a}^{*}$ & $\mathrm{~b}^{*}$ \\
\hline 2018 & -0.5 & $-0.9^{*}$ & 0.3 & 0.3 & -0.7 & -0.6 & $-0.8^{*}$ & 0.5 & -0.5 & -0.3 & -0.7 & $-0.9^{*}$ \\
2019 & 0.5 & 0.7 & 0.1 & 0.2 & 0.3 & 0.8 & -0.4 & -0.9 & 0.9 & 0.5 & 0.6 & 0.6 \\
\hline
\end{tabular}

${ }^{*} \mathrm{p}<0.05$; $\mathrm{C} 1$ : chloride content in raw processed beans; $\mathrm{KL}$ : potassium leaching; $\mathrm{pH}$ : bean $\mathrm{pH}$; TTA: total titratable acidity; ECND: electrical conductivity of non-defective beans; ECD: electrical conductivity of defective beans; $S>15$ : sieves larger than 15 ; $S<15$ : sieves smaller than 15 ; $L^{*}, a^{*}$ and $b^{*}$ : colorimetric parameters

Table 8: Pearson correlation between $\mathrm{C} 1$ content and quality indexes of processed coffee beans submitted to different $\mathrm{K}$ fertilization managements.

\begin{tabular}{cccccccccccccc}
\hline Year & Notes & $\mathrm{KL}$ & $\mathrm{pH}$ & $\mathrm{TTA}$ & Moisture & ECND & ECD & $\mathrm{S}>15$ & $\mathrm{P}<15$ & $\mathrm{~L}^{*}$ & $\mathrm{a}^{*}$ & $\mathrm{~b}^{*}$ \\
\hline 2018 & -0.5 & 0.7 & -0.3 & 0.6 & 0.6 & 0.2 & 0.5 & -0.5 & 0.5 & $0.8^{*}$ & 0.7 & 0.2 \\
2019 & 0.5 & 0.4 & 0.3 & $0.9^{*}$ & 0.5 & 0.4 & -0.3 & -0.2 & 0.2 & $0.8^{*}$ & 0.6 & -0.2 \\
\hline
\end{tabular}

*significant at $5 \%$ probability; $\mathrm{C} 1$ : chloride content of processed raw beans; $\mathrm{KL}$ : potassium leaching; pH: bean pH; TTA: total titratable; ECND: electrical conductivity of non-defective beans; ECD: electrical conductivity of defective beans; $S>15$ : sieves larger than 15; $\mathbf{S}<15$ : sieves smaller than $15 ; L^{*}, a^{*}$ and $b^{*}$ : colorimetric parameters. 
in $\mathrm{C} 1$ content of beans with the use of $\mathrm{KC} 1$ as compared to $\mathrm{Cl}$ content in coffee trees fertilized with other sources. It was also observed that the replacement of $\mathrm{KC} 1$ fertilization by $\mathrm{K}_{2} \mathrm{SO}_{4}$ improved the coffee quality, which was attributed to a decrease in $\mathrm{C} 1$ of beans, leading to an increase in the enzymatic activity of polyphenol oxidase (PPO) and improvement in color and in total sugar indexes of beans.

Silva et al. (2002) concluded that the replacement of $\mathrm{KC} 1$ with sources free from $\mathrm{C} 1, \mathrm{~K}_{2} \mathrm{SO}_{4}$, and $\mathrm{KNO}_{3}$ enhances the beverage quality. According to the authors, the best response from $\mathrm{Cl}$-free sources in the classification of coffee beverage was probably due to the partial influence of moisture on the fruits. These alterations trigger chemical reactions that modify the original chemical composition and the integrity of cell membranes that are responsible for maintaining the desirable sensory and aromatic attributes of coffee which, when ruptured, can end up exposing oils and lipid drops to oxidation, thus altering the aroma and flavor of coffee (Borém; Marques; Alves, 2008).

Although the replacement of $\mathrm{KCl}$ by $\mathrm{K}_{2} \mathrm{SO}_{4}$ has decreased the $\mathrm{Cl}$ content of beans, no significant correlations were observed between this parameter and the results of the sensory analysis, i.e., the quality scores assigned by tasters of specialty coffee. Despite of not decreasing the $\mathrm{C} 1$ content in beans, the foliar application of $\mathrm{K}_{2} \mathrm{SO}_{4}$ (T6) changed the sensory rating for the $2017 / 2018$ harvest, rating the drink in the special grade ( 80 points).

The analysis of the data through the analysis of variance and comparison of means did not prove to be efficient to detect differences among the treatments (Brighenti; Cirillo, 2018) highlighted the statistical difficulties in evaluating coffee classification.

Likewise, several studies also reported no significant correlations between the sensory analysis and the different types of coffee tree management (Silva et al., 2002; Siqueira; Abreu, 2006). Carvalho et al. (1994) pointed out that in view of the historical importance of coffee farming in Brazil, the application of objective physical-chemical methods conjointly with the sensory analysis would result in more accurate and reliable assessments of coffee beverage. In a wide bibliographic review on mineral nutrition of coffee trees and the quality of the beverage, Martinez et al. (2014) reported some studies that correlate sensory analysis findings with physical-chemical characteristics. Among those characteristics, the authors highlighted, in addition to PPO, the relationship between good quality beans with color $\mathrm{pH}$, total titratable acidity, EC and KL indexes.

In the present study, substantial correlations were observed between the sensory analysis and EC, KL and color index, especially in the high yield harvest (2017/2018). It was found that the higher the quality score obtained in sensory analysis, the lower the indexes of $\mathrm{EC}, \mathrm{KL}$ and bean color. $\mathrm{KL}$ and $\mathrm{EC}$ of beans decreased after replacing $50 \%$ of $\mathrm{K}$ fertilization via $\mathrm{KCl}$ by $\mathrm{K}_{2} \mathrm{SO}_{4}$, and also with supplemental foliar application with $\mathrm{K}_{2} \mathrm{SO}_{4}$. The greater the damage to the bean, the greater the amount of $\mathrm{K}$ ions translocated to liquid environment, resulting in an increase in EC, which is a strong indicator of damages to the membrane and cell wall (Goulart et al., 2007). High KL and EC values indicate damage to membranes and cell wall, which are associated with coffee beans classified with scores below 80 and worse beverage quality as determined by sensory analysis (Goulart et al., 2007).

Regarding the color indexes, a negative correlation was observed between quality and " $\mathrm{b}$ *" parameter scores for the 2017/2018 harvest. In treatments T4 and T5 (75\% and $100 \% \mathrm{~K}_{2} \mathrm{SO}_{4}$ ), a $6 \%$ decrease in undesirable yellow color and an increase in desirable blue color were observed in relation to treatment $\mathrm{T} 1$. It was also observed a $5 \%$ decrease in the value of " $\mathrm{L} *$ " in relation to $\mathrm{T} 1$ and $\mathrm{T} 2$ treatments after replacing $50 \%$ of $\mathrm{KCl}$ source by $\mathrm{K}_{2} \mathrm{SO}_{4}$. The foliar application of $\mathrm{K}_{2} \mathrm{SO}_{4}$ also increased the value of " $\mathrm{L} *$ " by $5 \%$ in the $2017 / 2018$ harvest.

The $L^{*}$ parameter presented a positive correlation with $\mathrm{C} 1$ content in beans of both harvests studied, i.e., the higher the $\mathrm{C} 1$ content, the higher the $\mathrm{L}^{*}$ index. High values of this index are not desired, since they indicate that the bean color is lighter. The results observed in this study corroborate the results obtained by several studies that observed a correlation between darker beans with higher scores in sensory analysis (Carvalho et al., 1994; Chagas et al., 1996; Silva et al., 2002).

Alterations in bean color may indicate the occurrence of oxidative processes and biochemical transformations of enzymatic nature that will play a negative role on the taste and aroma of the beverage (Isquierdo et al., 2011). During storage, changes in bean color and losses in quality occur as the storage time extends, turning the bluish-green hue, which characterizes good quality, into a light brown and whitish color, thus producing the "whitening" of the bean (Carvalho; Chagas; Souza, 1997).

Although TTA decreased with the application of the highest proportions of $\mathrm{K}_{2} \mathrm{SO}_{4}$ in coffee beans from the two studied harvests, this decrease was not statistically significant by the comparison of means test. However, for the 2018/2019 harvest a positive correlation of $\mathrm{C} 1$ content and beans with TTA was observed, i.e., the higher the bean $\mathrm{Cl}$ content, the greater the TTA. Silva et al. (1999) identified lower values of acidity in coffee beans fertilized with $\mathrm{K}_{2} \mathrm{SO}_{4}$. Malta, Nogueira and Guimarães (2003) also observed a decrease in TTA indexes after the use of $\mathrm{K}$ sources free of $\mathrm{C} 1$.

The $\mathrm{pH}$ of beans showed no variations as a result of $\mathrm{K}$ fertilization with mean values ranging from 4.9 to 5.1 . Fernandes et al. (2003) emphasized the role $\mathrm{pH}$ plays on the product acceptance by consumers and demonstrated that the ideal $\mathrm{pH}$ ranges between 4.9 and 5.2, making the beverage 
palatable without excessive bitterness or acidity. This is an indication that it is not likely that this parameter suffers any influence from $\mathrm{K}$ sources used in coffee plantation.

The foliar application of $\mathrm{K}_{2} \mathrm{SO}_{4}$ at $3 \% \mathrm{~m} / \mathrm{m}$ resulted in larger coffee beans in comparison with treatments receiving only $\mathrm{K}$ fertilization in the soil, i.e., an $8 \%$ increase in relation to treatments that received highest proportions of $\mathrm{KCl}$ on soil, and a $2 \%$ increase in larger beans as compared to treatments that received $75 \%$ and $100 \%$ of $\mathrm{K}$ fertilization on soil only through $\mathrm{K}_{2} \mathrm{SO}_{4}$ applications in the 2018/2019 harvest.

In general, it was observed that foliar $\mathrm{K}_{2} \mathrm{SO}_{4}$ applications improved coffee quality. Even though no specific studies are yet available on supplemental foliar $\mathrm{K}$ application to coffee aiming to improve quality, studies on different crops, such as melon, pear, potato, and apple, among others, have shown that the foliar application of $\mathrm{K}$ can enhance the quality of products (Jifon; Lester, 2009; Dkhil; Denden; Aboud, 2011; Salim; Abd El-Gawad; Abou El-Yazied, 2014; Shen et al., 2016; Solhjoo; Gharaghani; Fallahi, 2017). Ali et al. (2016) found that foliar spraying at $2 \%$ and $3 \% \mathrm{~K}_{2} \mathrm{O}$ improved bean quality of hybrid corn, in comparison with application of $75 \mathrm{~kg} \mathrm{~K}_{2} \mathrm{O}$ ha $^{-1}$ to the soil. Dalal and Beniwal (2017) conducted a field study to estimate the impact of foliar application of different sources of $\mathrm{K}$ on sweet orange cv Jaffa and concluded that $\mathrm{K}_{2} \mathrm{SO}_{4}$ foliar application at $2 \%$ and $3 \%$ increased the chemical quality of sweet orange. The results obtained from the present study demonstrated that this technique can attenuate the effects of $\mathrm{Cl}$ on the quality of coffee beverage as much as the replacement of $\mathrm{KCl}$ source by $\mathrm{K}_{2} \mathrm{SO}_{4}$.

The relationships between chemical or physical attributes, such as KL, EC or bean color and coffee sensory evaluations indicate the potential of using these measures as an additional tool to achieve a more secure and reliable classification of the beverage.

\section{CONCLUSIONS}

- Total or partial replacement (at least $50 \%$ of $\mathrm{K}_{2} \mathrm{O}$ dose) of $\mathrm{KCl}$ by $\mathrm{K}_{2} \mathrm{SO}$ in the soil as well as the supplemental foliar application of $\mathrm{K}_{2} \mathrm{SO}_{4}$ change chemical characteristics and color of processed raw coffee beans.

- Bean $\mathrm{Cl}$ contents do not show any correlation with sensory analysis.

Supplemental application of $\mathrm{K}_{2} \mathrm{SO}_{4}$ on leaf combined with soil applications of $\mathrm{KCl}$ made it possible to classify the coffee beverage in a higher class according to the SCA classification.

- Evaluation of potassium leaching, electrical conductivity and color of beans can be used to provide additional support for the improvement of sensory analysis of coffee beans.

\section{REFERENCES}

ABID, M.; SCHNEIDER, U. A.; SCHEFFRAN, J. Adaptation to climate change and its impacts on food productivity and crop income: perspectives of farmers in rural Pakistan. Journal of Rural Studied, 47:254-266, 2016.

ALI, A. et al. Foliar spray surpasses soil application of potassium for maize production under rainfed conditions. Turkish Journal of Field Crops, 21(1):36-43, 2016.

ASSOCIATION OF OFFICIAL AGRICULTURAL CHEMISTS - AOAC. Official methods of analysis of the association of official analytical chemist. Inc., Washington, USA, $21^{\mathrm{a}}$ st. 2019. 3320p

BORÉM, F. M.; MARQUES, E. R.; ALVES, E. Ultrastructural analysis of drying damage in parchment Arabica coffee endosperm cells. Biosystems Engineering, 99(1):62-66, 2008.

BRIGHENTI, C. R. G.; CIRILlO, M. A. Analysis of defects in coffee beans compared to biplots for simultaneous tables. Revista Ciência Agronômica, 49(1):62-69, 2018.

CAMARGO, O. A. et al. Métodos de análise química, mineralógica e física de solos do Instituto Agronômico de Campinas. Campinas: Instituto Agronômico, 2009. 94p. (Boletim Técnico, 106).

CARVALHO, V. D. et al. Relação entre a composição físicoquímica e química do grão beneficiado e a qualidade de bebida do café. Pesquisa Agropecuária Brasileira, 29(3):449-454, 1994.

CARVALHO, V. D.; CHAGAS, S. J. R.; SOUZA, S. M. C. Fatores que afetam a qualidade do café. Informe Agropecuário, 18(187):5-20, 1997.

\section{CENTRO INTEGRADO DE INFORMAÇÕES} AGROMETEOROLÓGICAS - CIAGRO. Temperatura média mensal. 2020. <Available in: http://www.ciiagro. sp.gov.br/ciiagroonline/MenuMonClim.htm>. Access in: June 2020.

CHAGAS, S. J. R. et al. Caracterização química e qualitativa de cafés de alguns municípios de três regiões produtoras de Minas Gerais. Pesquisa Agropecuária Brasileira, 31(8):555-561, 1996.

DALAL, R. P. S.; BENIWAL, B. S. Influence of foliar sprays of different potassium fertilizers on quality and leaf mineral composition of sweet orange (Citrus sinensis cv. Jaffa). International Journal of Pure \& Applied. Bioscience, 5(5):587-594, 2017. 
DKHIL, B. B.; DENDEN, M. D.; ABOUD, S. Foliar potassium fertilization and its effect on growth, yield and quality of potato grown under loam-sandy soil and semiarid conditions. International Journal of Agricultural Research, 6(7):593-600, 2011.

ERNANI, P. R.; ALMEIDA, J. A.; SANTOS, F. C. Potássio. In: NOVAIS, R. F. et al. Fertilidade do solo. Viçosa: SBCS/ UFV, p. 551-594, 2007.

FERNANDES, S. M. et al. Constituintes químicos e teor de extrato aquoso de cafés arábica (Coffea arabica L.) e conilon (Coffea canephora pierre) torrados. Ciência e Agrotecnologia, 27(5):1076-1081, 2003.

GODINHO, R. P. et al. Variações na cor e na composição química do café (Coffea arabica L.) armazenado em coco e beneficiado. Revista Brasileira de Armazenamento, (1):38-43, 2000.

GOULART, P. F. P. et al. Aspectos histoquímicos e morfológicos de grãos de café de diferentes qualidades. Ciência Rural, 37(3):662-666, 2007.

ISQUIERDO, E. P. et al. Qualidade do café cereja desmucilado submetido ao parcelamento da secagem. Coffee Science, 6(1):83-90, 2011.

JIFON, J. L.; LESTER, G. E. Foliar potassium fertilization improves fruit quality of field-grown muskmelon on calcareous soils in south Texas. Journal of the Science of food and Agriculture, 89(14):2452-2460, 2009.

MALAVOLTA, E.; VITTI, G. C.; OLIVEIRA, S. A. Avaliação do estado nutricional das plantas. Piracicaba: POTAFÓS, 1997. 319p.

MALTA, M. R.; NOGUEIRA, F. D.; GUIMARÃES, P. T. G. Composição química, produção e qualidade do café fertilizado com diferentes fontes e doses de nitrogênio. Ciência e Agrotecnologia, 27(6):1246-1252, 2003.

MALTA, M. R.; PEREIRA, R. G. F. A.; CHAGAS, S. J. R. Condutividade elétrica e lixiviação de potássio do exsudato de grãos de café: alguns fatores que podem influenciar essas avaliações. Ciência e Agrotecnologia, 29(5):1015-1020, 2005

MANCUSO, M. A. C. et al. Efeito de fontes e taxas de potássio na produção, nutrição e exportação de macronutrientes do café arábica. Revista Brasileira de Ciências do Solo, 38(5):1448-1456, 2014.

MARQUES, E. R. et al. Eficácia do teste de acidez graxa na avaliação da qualidade do café arábica (Coffea arabica L.) submetido a diferente períodos e temperaturas de secagem. Ciência e Agrotecnologia, 32(5):1557-1562, 2008.
MARTINEZ, H. E. P. et al. Nutrição mineral do cafeeiro e qualidade da bebida. Revista Ceres, 61(7):838-848, 2014.

MATIELLO, J. B. et al. Cultura de café no Brasil: Manual de recomendações. Rio de Janeiro: Fundação Procafé, 2010. 546p.

MINOLTA. Precise color communication, Color control from perception to instrumentation. Japan, 1998. 59p.

RAIJ, B. V. et al. Análise química para avaliação da fertilidade de solos tropicais. Campinas: Instituto Agronômico. 2001. 285p.

RAIJ, B. V. et al. Recomendações de adubação e calagem para o Estado de São Paulo. 2.ed. rev. atual. Campinas: Instituto Agronômico, 1997. 285p. (Boletim técnico, n.100).

SALIM, B.; ABD EL-GAWAD, H.; ABOU EL-YAZIED, A. Effect of foliar spray of different potassium sources on growth, yield and mineral composition of potato (Solanum tuberosum L.). Middle East Journal of Applied Sciences, 4(4):1197-1204, 2014.

SHEN, C. et al. Effects of foliar potassium fertilization on fruit growth rate, potassium accumulation, yield, and quality of 'Kousui' japanese pear. Hort technology, 26(3):270-277, 2016.

SILVA, E. B. et al. Fontes e doses de potássio na produção e qualidade do grão de café beneficiado. Pesquisa Agropecuária Brasileira, 34(3):335-345, 1999.

SILVA, E. B. et al. Resposta do cafeeiro à adubação potássica em safras de baixa e alta produção. Pesquisa Agropecuária Brasileira, 36(11):1331-1337, 2001.

SILVA, E. B.; NOGUEIRA, F. D.; GUIMARÃES, P. T. G. Qualidade de grãos de café beneficiados em resposta à adubação potássica. Scientia Agricola, 59(1):173-179, 2002.

SIQUEIRA, H. H. E.; ABREU, C. M. P. Composição físico-química e qualidade do café submetido a dois tipos de torração e com diferentes formas de processamento. Ciência e Agrotecnologia, 30(1):112117, 2006.

SOLHJOO, S.; GHARAGHANI, A.; FALLAHI, E. Calcium and potassium foliar sprays affect fruit skin color, quality attributes, and mineral nutrient concentrations of 'red delicious' apples. International Journal of Fruit Science, 17(4):358-373, 2017.

SPECIALTY COFFEE ASSOCIATION - SCA. Protocols: cupping speciality coffee. 2012. Available in: <https:// sca.coffee/research/protocols-best-practices $>$. Access in: August, 2019. 